\title{
THE MODELLING TARIFF OF SOLID WASTE MANAGEMENT RETRIBUTIONS FOR MALANG CITY
}

Siti Maisyah, Trijoko Wahyu Adi and I.D.A.A Warmadewanthi

Department of Civil Engineering, Sepuluh Nopember Institute of Technology, Surabaya, Indonesia

E-Mail: s_maisyah@yahoo.co.id

\begin{abstract}
Cost of solid waste management, in Malang City, can not be covered by retribution; therefore government has to subsidized. Solid waste management expense consist of TPS (temporary collection location/Tempat penampungan sementara) investment, operational/maintenance of TPS, wipe of general facility, transport from TPS to landfill and landfill treatment. This study suggest tariff retribution calculation model of solid waste mangement at Malang City. The proposed model integrate 2 method, they are Activity Based Costing (ABC) system and building type. Activity Based Costing (ABC) system is used to gather cost of waste management. While building type is used to put cost upon tariff retribution of waste management at Malang City. The early stages was to identify any activities that generate expenses in waste management. The next phase is determining the cost driver from each activites. The last step is devide amount retribution based on building type. The result from this study show that cost of street sweeping is Rp. 6.275,35/km; cost of transporting solid waste is Rp. 96.832,40/trip and cost of landfill treatment is Rp. $6.275,35 / \mathrm{m}^{3}$. After that, calculate based on solid waste generated each type building.
\end{abstract}

Keywords : solid waste management, Activity Based Costing, building type, retribution tariff and Malang City.

\section{INTRODUCTION}

Cleaning and landscaping agency, Malang City are fully responsible for the solid waste management system, including sweeping, collection, solid waste transportation and final solid waste management. Regional Regulation No. 1/2011 on Public service retribution Malang city became the basis of fee collection services solid Waste and cleanness in the community which is calculated based on the function of the building. Adjustment of the tariff must be done so that adequate operational and maintenance costs.

One of the problems in the financing of solid waste management is facing, operational and maintenance costs can not be covered from the retributions, so that local governments have to subsidize. Imposition of retributions made Malang based on the type of building function beneficiaries. The method is quite good because of the imposition of the tariff in accordance with the amount of solid waste generated. But the weakness of this method is the amount of the tariff determined by agreement between the regional government with little modification and do not include the cost of servicing public facilities that have not been able to achieve cost recovery. The collection and processing of data on activities based costing need to be used to understand and control costs.

This Tariff retribution model proposed in this study combines the advantages of the model retribution that uses type function building used by DKP of Malang and ABC Method, so they can obtain a better model.

\section{LITERATURE REVIEW Retribution}

According to Constitution regulation No. $28 / 2009$, the retribution is local charges as payment for services or certain special permits provided and / or supplied by the regional government for the benefit of individuals or entities. Service Fees Waste / Hygiene levy collected as payment for services provided by local governments in collecting, transporting and providing the location of waste processing.
Constitution regulation No. 34/2000 Section 21 and Government Regulation No. 66/2001 Section 8-10 states the principles and objectives in the tariff retribution are set by regional policy taking into account the cost of providing services is concerned, the ability of people, and aspects of justice.

To assess the effectiveness of the collection of retribution, there are several criteria that must be met : a. Adequacy and elasticity

b. Justice

c. Administration capabilities

d.Government Regulation On Retribution

\section{Cost}

According to Mulyadi (2010) the cost of the sacrifice of economic resources, measured in units of money, which have occurred or are likely to occur for a particular purpose. Carter and Usry (2006) states that the cost is the exchange rate. Spending on benefit. Costs have various meanings depending on the level of usefulness. Cost is defined as the value that we have to spend to get a good.

An object of the cost (cost object) is defined as an item or cost objectives is defined as an item or activity that costs are accumulated and measured. Classification is based on the relationship between the cost of the product (one lot, batch or unit of a finished goods or services), production volumes, departments/processes/cost centers, time period and a decision/action.

\section{Building Functions}

The function of the building is a form of human activity in the building, whether residential, religious, business, social/cultural and special events activities.

Building functions based on Contitution regulation No. 18/2008 regarding the management of household solid waste and similar household, consisting of:

1. Settlement

2. Market 
3. Commercial/office

4. Road/park

\section{ABC (Activity Based Costing)}

According Horngren (2008) defines the ABC (Activity Based Costing) as a system of calculating the cost of each activity as well as the charge to cost objects such as products and services based on the activities required to produce each product and service. According Hariadi (2002) says there are four levels of activity, is as follows:

1. Unit Level Activities

2. Batch Level Activities

3. Product Sustaining Activities

4. Facility Sustaining Activities

According to Hansen and Mowen (2006), there are six steps in the design of the ABC system, namely:

1. Activity Identification, definition and classification

2. Assign a cost to activites

3. Assigning costs to primary and secondary activity activities

4. Cost object and bills of activities

5. Activity rates and product costing

There are several types of cost drivers that can be used when designing the ABC system:

1. Volume

2. Transaction

3. Length of time

\section{Solid Waste}

Garbage is solid waste originating from the activities of humans and animals, which must be disposed of as useless or unwanted again (Tchobanoglous, et. Al., 1993). According to Constitution regulation No. 18/2008, Garbage is the rest of the daily activities of human and/or natural processes in the solid form.

Waste management is defined as an effort to control the waste handling process. Ranging from generation, lug, collection, transportation and handling in the landfill. Technical management of garbage includes 6 elements function (Peavy, et. Al., 1985):

1. Shelter and processing at the source of waste.

2. The collection of garbage at source.

3. The temporary shelter.

4. Removal of conveyance.

5. Transportation.

6. The place of final processing.

Factors that affect the urban waste management system is (SNI 19-2454-2002):

1. density and population distribution;

2. Characteristics of the physical environment, biological and socio-economic;

3. Generation and characteristics of waste;

4. Cultural attitudes and behavior;

5. Distance from the source of waste to landfill;

6. Spatial planning and urban development;

7. Means of collection, transportation, treatment and disposal of garbage;

8. Costs are available;

9. Regulation of the local area;

SNI-03-3242-1994 governing the procedure for waste management in the settlements, estimating financing ratio of total waste management, namely: 1. The cost of collecting $20-40 \%$

2. The cost of transporting $40-60 \%$

3. The cost of final disposal of $10-30 \%$

Although the cost of final disposal has the smallest percentage, but when applied to proper waste management systems can provide benefits, especially in supporting the operational landfill itself.

The structure of waste management costs can be classified as follows:

1. The cost of the investment, including:

2. Operating costs and maintenance, include:

Target of the financing of waste management are:

a. Meet the need for the provision of services in accordance with minimum standards

b. Waste management in potential areas (residential, commercial areas, offices and industry) which is the object of the levy is targeted to be financed from the withdrawal of a levy on services received (cost recovery).

c. If not able to achieve cost recovery, then the government should provide subsidies through the budget, so there is no degradation of service that may interfere with the environment and public health. However, this subsidy should be pursued continuously decreases with the increasing acceptance of the results of the levy through the intensification and adjustment levy rates.

Guidelines for setting the amount of the tariff is:

a. Conducting a needs analysis of municipal waste management costs and determine the amount of annual expenses budget requirements.

b. Analyzing separately the cost requirements for organizing street cleaning services and public facilities that are not funded by a levy cleanliness of the budget that will be used to provide services to the service user.

c. Projecting the budget for each designated for a certain period of time, taking into account the increase in service coverage and the generation volume and inflation.

d. Results of budget projections the cost of waste management and public facilities become a reference for determining the allocation of budget from sources other than the levy hygiene city revenue, while the projected budget for the service user services become a reference for determining the amount of the tariff.

e. Analysis of the needs of the average annual cost for care service users by summing budget projected in the previous point and divided by the projection period. The average annual cost of this to be the representation of the cost requirements during the projection period.

f. Analysis of the needs of the average monthly cost by dividing the average annual cost by 12 (the number of months in a year). Results of this analysis the target of retribution hygiene to achieve cost recovery and be a reference for determining the amount of levy to be paid for the service user.

g. Determination of the tariff is based on the unit cost of service, which contains the mission of the reduction of waste generation. Service users, tariffs on services levy per unit volume / weight of waste generated. For that to be counted also the cost of waste management units per cubic meter of waste to be managed. 
h. The application of tariffs through the principles of cross-subsidies, where the services of commercial areas subsidize the service users of residential and social activities. Also carried out cross-subsidies in the group housing, in which high-income service users subsidize low income.

\section{METHODS}

Activities that are value added and non value added to the solid waste management system/cleanness at Malang city determined beforehand. In general, Schematic solid waste management system can be observed in Figure 1.

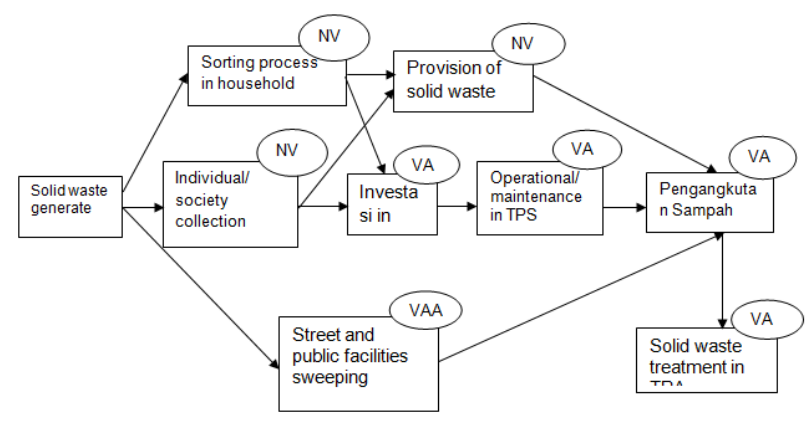

Figure 1 Schematic Solid Waste Management System

Activities that are value added is the activities of street sweeping, waste transport and management of solid waste in the landfill. These activities are managed directly by local governments that contribute to value and and meet the needs of management organization which in this case is the Cleaning and landscaping agency at Malang city. As for the waste sorting activities, lug trash and garbage collection is an activity that is non-value added because it is done individually and NGOs so as not to contribute to customer value or needs of the organization.

The activities have been classified that can be identified in the study variables as follows:

1. Investment TPS

a. The volume of waste that goes to the polls

b. Equipment and supplies used

2. Management and maintenance of TPS

a. Total manpower/personnel

b. Equipment and supplies used

3. Sweeping path becomes variable in this activity are:

a. Road length/channel

b. Total manpower/personnel

c. Working time

d. Equipment and conveyances used

4. Transportation garbage variables consist of:

a. Number ritasi

b. Total manpower

c. Travel time per ritasi (including operating time)

d. Mileage

e. The volume of waste transported each ritasi

f. Fuel consumption

g. Fleet number conveyance

h. Equipment and supplies used

5. Management of waste in the landfill, variables consist of:

a. The amount of labor in the landfill b. The amount of heavy equipment

c. The amount of equipment and supplies

d. Fuel consumption for heavy equipment

e. The volume of waste that goes to landfill

f. Suggestions and infrastructure in landfill including means of supporting

Processing and calculation of data can be described as follows:

1. Analysis by ABC.

a. Analysis of the flow of activities and costs incurred in the waste management system. These activities can be classified in the Value Added Activity (VAA) in Figure 1.

b. Identify the cost driver (the cost driver) of each of those activities

2. Divide the amount of the levy is based on the function of the building.

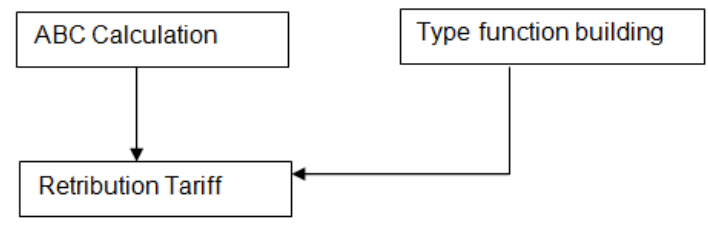

Figure 2 Calculation of Retribution

\section{RESULT AND DISCUSSIONS}

\section{Determination of Cost Pool and Cost Drivers}

In the next stage in the ABC system is a set cost pool used to collect the fees stated in "Rupiah". On the services of cleanliness, there are 3 (three) cost pool that is sweeping (cost pool A), transportation (cost pool B) and landfill management (cost pool C). The next step is to set the trigger cost (cost driver) used as a measure of activity that raises the cost drivers hygiene services. Cost-peractivity set of drivers that cause costs. The cost driver hygiene services at street sweeping activity is expressed in units "km", to the activity of transporting waste to ritasi expressed in units of "trip" and for waste management activities in landfill expressed in the unit " $\mathrm{m}^{3}$ ".

\section{Road Sweeping Cost}

At street sweeping activities done by the Cleaning and Landscapping Agency obtained through cost incurred on these activities. Costs consist of personnel costs, equipment costs, fuel cost for supervisor vehicles, oil and parts cost for supervisor vehicle. Street sweeping recapitulation costs contained in the table 1 :

Table 1. Road Sweeping Cost

\begin{tabular}{|c|l|r|}
\hline No & \multicolumn{1}{|c|}{ Description } & \multicolumn{1}{|c|}{$\begin{array}{c}\text { Cost } \\
\text { (Rp/year) }\end{array}$} \\
\hline 1 & Cost Officer (Direct Labor Costs) & 13.260 .672 .000 \\
\hline 2 & Operation and maintenance Cost & \\
\hline & a. Equipmet & 140.050 .000 \\
\hline & b. BBM & 14.994 .000 \\
\hline & c. Oil machine & 564.000 \\
\hline & d. Tire & 770.000 \\
\hline & e. service motorcycle & 660.000 \\
\hline
\end{tabular}


Total

13.417.710.000

From the calculation in the table above, costs incurred from street sweeping activities is Rp. 13.417.710.000,-, which is mostly used to direct labour cost.

\section{Freight Waste Cost}

Costs incurred on freight waste activities is workers and supervisors cost, dump trucks and arm roll truck driver costs, driver salaries based on number of trips, waste worker salaries, supplies and equipment costs, fuel for waste trucks cost, service, maintenance, and parts costs. Recapitulation of the freight waste costs contained in Table 2 below.

Table 2. Freight Waste Costs

\begin{tabular}{|l|l|r|}
\hline No & \multicolumn{1}{|c|}{ Description } & \multicolumn{1}{c|}{$\begin{array}{c}\text { Cost } \\
\text { (Rp/year) }\end{array}$} \\
\hline 1 & Direct labor costs & 736.800 .000 \\
\hline & Driver salaries & $\begin{array}{l}\text { Operations and Maintenance } \\
\text { Costs }\end{array}$ \\
\hline & Fuel & 1.475 .275 .000 \\
\hline & Service and maintenance & 35.600 .000 \\
\hline & Parts Total & 30.000 .000 \\
\hline & \multicolumn{2}{|c|}{ Ton } \\
\hline
\end{tabular}

From the calculation above, total costs for freight waste activities is Rp. 2.277.675.000,-.

\section{Landfill Waste Treatment Cost}

Costs incurred on landfill waste treatment cost is personnel and labor costs, fuel costs, fuel costs for trucks and heavy equipment, service and parts costs. , the cost of lubricants needs of heavy equipment and trucks of land, the cost of services, the service and the cost of replacement parts. Recapitulation of the freight waste costs contained in Table 3 below :

Table 3. Landfill Waste Treatment Costs

\begin{tabular}{|l|l|r|}
\hline No & \multicolumn{1}{|c|}{ Description } & \multicolumn{1}{|c|}{$\begin{array}{c}\text { Cost } \\
\text { (Rp/year) }\end{array}$} \\
\hline 1 & Direct labor costs & 626.796 .000 \\
\hline 2 & $\begin{array}{l}\text { Operations and Maintenance } \\
\text { Costs }\end{array}$ & \\
\hline & a. Fuel & 572.962 .500 \\
\hline & b. Service and maintenance & 7.750 .000 \\
\hline & c. Parts & 5.300 .000 \\
\hline \multicolumn{2}{|l|}{ Total } & 1.212 .808 .500 \\
\hline
\end{tabular}

Source: Data processed, Department of Hygiene and 2014

From the calculation above, total costs for freight waste activities is Rp. 1.212.808.500,--

\section{Miscellaneous Cost}

There are other costs that occured in road sweeping, freight waste and landfill waste treatment activities above. That costs such as facilities and infrastructure supply for waste management costs, operation and maintenance for waste facilities and infrastructure, waste management cooperation cost, and dissemination for waste management policy cost. Summary for Miscellaneous Cost can be seen in table 4 below :

Table 4. Miscellaneous Cost

\begin{tabular}{|c|l|c|}
\hline No & \multicolumn{1}{|c|}{ Description } & \multicolumn{1}{|c|}{$\begin{array}{c}\text { Total } \\
\text { (Rp) }\end{array}$} \\
\hline 1 & $\begin{array}{l}\text { Facilities and infrastructure } \\
\text { supply for waste management }\end{array}$ & 2.837 .052 .000 \\
\hline 2 & $\begin{array}{l}\text { Waste management cooperation } \\
\text { cost }\end{array}$ & 184.351 .000 \\
\hline 3 & $\begin{array}{l}\text { Dissemination for waste } \\
\text { management policy }\end{array}$ & 52.850 .000 \\
\hline \multicolumn{2}{|c|}{ Total } & 3.074 .253 .000 \\
\hline
\end{tabular}

Costs incurred be in form of Direct Labor Costs (BTKL) and Operational and Maintenance costs. Cost proportion for waste management activities can be seen in table 5 below :

Table 5. Total costs incurred and the proportion of the Waste Management Activities

\begin{tabular}{|c|c|c|c|c|c|c|}
\hline No & Serrice & $\begin{array}{c}\text { Total Cost } \\
(\mathbb{R p})\end{array}$ & $\operatorname{BTKL}(\mathbb{R p})$ & $\begin{array}{c}\text { Proportion } \\
(96)\end{array}$ & $\begin{array}{c}\text { Operation } \\
\text { Maintenance } \\
\left(\mathbb{R}_{p}\right)\end{array}$ & $\begin{array}{l}\text { Proporti } \\
\text { ou }(90)\end{array}$ \\
\hline T & Road Swesping & 13.417 .710 .000 & 13260.672000 & 90,68 & 157.038000 & 6,88 \\
\hline & Feight Wiats & 2217.675 .000 & & 5,04 & 1540.855000 & 67,4 \\
\hline 3 & $\begin{array}{l}\text { Landfill Waste } \\
\text { Treatment }\end{array}$ & 1.212 .808 .500 & 626.966 .000 & 4,28 & 5860.012500 & 25,65 \\
\hline Tots & & & 14.624 .265 .000 & 100 & 2.283925 .500 & 100 \\
\hline
\end{tabular}

Direct Labor Costs (BTKL) are all costs that associated with wages and salaries for workers and labor that directly involved in waste management activities. Operations and maintenance costs consist of costs for equipment and supplies, fuel/lubricant, also service and parts.

Costs that generated from other waste management activities, will be allocated to direct labour cost and operation and maintenance cost based on proportion. The calculation can be seen in table 6 below :

Table 6. Waste Management Performance Development Costs for Waste Service Support

\begin{tabular}{|c|l|c|c|c|}
\hline No & Description & $\begin{array}{c}\text { BTKL } \\
\text { (Rp) }\end{array}$ & $\begin{array}{c}\text { O\&M } \\
\text { (Rp) }\end{array}$ & $\begin{array}{c}\text { Total } \\
\text { (Rp) }\end{array}$ \\
\hline 1 & $\begin{array}{l}\text { Infrastucture } \\
\text { and facilities } \\
\text { supply for } \\
\text { waste } \\
\text { management }\end{array}$ & - & 2.837 .052 .000 & 2.837 .052 .000 \\
\hline 2 & $\begin{array}{l}\text { Waste } \\
\text { management } \\
\text { cooperation }\end{array}$ & 43.100 .000 & 141.251 .000 & 184.351 .000 \\
\hline 3 & $\begin{array}{l}\text { Dissemination } \\
\text { for waste } \\
\text { management }\end{array}$ & 31.900 .000 & 20.950 .000 & 52.850 .000 \\
\hline \multicolumn{2}{|c|}{ Total } & 75.000 .000 & 2.999 .253 .000 & 3.074 .253 .000 \\
\hline
\end{tabular}


The 2nd International Conference on Civil Engineering Research (ICCER) 2016

"Contribution of Civil Engineering toward Building Sustainable City"

Operation and maintenance costs and Direct Labor Costs in table 6 above, will be allocated according to the proportion (\%) contained in Table 7 and added to the waste service costs. Allocation result from operation and maintenance cost contained in tables 8 and table 9 . Allocation result for direct labor costs contained in table 10 and table 11 .

Table 7. Cost Allocation for Operation and Maintenance of Waste Management

\begin{tabular}{|c|l|c|r|}
\hline No & Activities & $\begin{array}{c}\text { Proportion } \\
(\mathbf{\%})\end{array}$ & $\begin{array}{c}\text { Total } \\
\text { (Rp) }\end{array}$ \\
\hline 1 & $\begin{array}{l}\text { Road } \\
\text { sweeping }\end{array}$ & 6,88 & 206.248 .606 \\
\hline 2 & Freight waste & 67,47 & 2.023 .595 .999 \\
\hline 3 & $\begin{array}{l}\text { Landfill waste } \\
\text { treatment }\end{array}$ & 25,65 & 769.308 .395 \\
\hline \multicolumn{2}{|c|}{ Total } & 100 & 2.999 .153 .000 \\
\hline
\end{tabular}

Then costs allocation in table 7 above, will be combined with undirect operation and maintenance cost, can be seen in table 8 below :

Table 8 Operation and Maintenance Cost of Waste Management

\begin{tabular}{|c|l|c|c|c|}
\hline No & Activities & $\begin{array}{c}\text { Before } \\
\text { Addition (Rp) }\end{array}$ & $\begin{array}{c}\text { Addition } \\
\text { (Rp) }\end{array}$ & $\begin{array}{c}\text { Total } \\
\text { (Rp) }\end{array}$ \\
\hline 1 & Roadsweeping & 157.038 .000 & 206.248 .606 & 363.286 .606 \\
\hline 2 & Freight waste & 1.540 .875 .000 & 2.023 .595 .999 & 3.564 .470 .999 \\
\hline 3 & $\begin{array}{l}\text { Landfill waste } \\
\text { treatment }\end{array}$ & 586.012 .500 & 769.308 .395 & 1.355 .320 .895 \\
\hline & Total & 3.679 .211 .600 & 2.999 .153 .000 & 5.283 .078 .500 \\
\hline
\end{tabular}

Table 9 Cost Allocation for Direct Labour Cost of Waste Management

\begin{tabular}{|c|l|c|r|}
\hline No & \multicolumn{1}{|c|}{ Activities } & $\begin{array}{c}\text { Proportion } \\
\text { (\%) }\end{array}$ & $\begin{array}{c}\text { Total } \\
\text { (Rp) }\end{array}$ \\
\hline 1 & Road sweeping & 90,68 & 68.010 .000 \\
\hline 2 & Freight waste & 5,04 & 3.780 .000 \\
\hline 3 & $\begin{array}{l}\text { Landfill waste } \\
\text { treatment }\end{array}$ & 4,28 & 3.210 .000 \\
\hline \multicolumn{2}{|c|}{ Total } & 100 & 75.000 .000 \\
\hline
\end{tabular}

Table 10 Direct Labour Cost of Waste Management

\begin{tabular}{|c|c|c|c|c|}
\hline No & Activities & $\begin{array}{c}\text { Before } \\
\text { Addition (Rp) }\end{array}$ & $\begin{array}{l}\text { Addition } \\
\text { (Rp) }\end{array}$ & $\begin{array}{l}\text { Total } \\
\text { (Rp) }\end{array}$ \\
\hline 1 & $\begin{array}{l}\text { Road } \\
\text { sweeping }\end{array}$ & 13.260 .672 .000 & 68.010 .000 & 13.328 .682 .000 \\
\hline 2 & $\begin{array}{l}\text { Freight } \\
\text { waste }\end{array}$ & 736.800 .000 & 3.780 .000 & 740.580 .000 \\
\hline 3 & $\begin{array}{l}\text { Landfill } \\
\text { waste } \\
\text { treatment }\end{array}$ & 626.796 .000 & 3.210 .000 & 630.006 .000 \\
\hline \multicolumn{2}{|r|}{ Total } & 2.141 .816 .000 & 75.000 .000 & 14.699 .268 .000 \\
\hline
\end{tabular}

Administration cost in Malang District Cleaning and Landscapping Agency budgeting used for support waste service activities in Malang District, next will be allocated to service activities, with proportion $6,88 \%$ for road sweeping, $67,47 \%$ for freight waste, and $25,65 \%$ for landfill waste treatment. Allocation for administration cost can be seen in table 11 below :

Table 11. Administration Cost of Waste Management

\begin{tabular}{|l|l|c|}
\hline No & \multicolumn{1}{|c|}{ Description } & \multicolumn{1}{|c|}{$\begin{array}{c}\text { Total } \\
\text { (Rp) }\end{array}$} \\
\hline 1 & Office administration program & 160.500 .000 \\
\hline 2 & $\begin{array}{l}\text { Infrastructure and facility officer } \\
\text { development program }\end{array}$ & 1.950 .000 .00 \\
\hline 3 & $\begin{array}{l}\text { Improvement and development } \\
\text { financial reporting system } \\
\text { program }\end{array}$ & 190.000 .000 \\
\hline \multicolumn{2}{|c|}{ Total } & 2.300 .500 .000 \\
\hline
\end{tabular}

Calculation result from table 11 above, will be allocated based on proportion of administration cost which can be seen in table 12 below :

Table 11 Administration Fee Sanitary Service Activity Support Services

\begin{tabular}{|c|l|c|r|}
\hline No & \multicolumn{1}{|c|}{ Activities } & $\begin{array}{c}\text { Proportion } \\
\text { (\%) }\end{array}$ & $\begin{array}{c}\text { Total } \\
\text { (Rp) }\end{array}$ \\
\hline 1 & Road sweeping & 6,88 & 158.274 .400 \\
\hline 2 & Freight waste & 67,47 & 1.552 .147 .350 \\
\hline 3 & $\begin{array}{l}\text { Landfill waste } \\
\text { treatment }\end{array}$ & 25,65 & 590.078 .250 \\
\hline \multicolumn{2}{|c|}{ Total } & 100 & 2.300 .500 .000 \\
\hline
\end{tabular}

Table 12 below was the identification result from activity and cost occured from waste management activities.

Table 12. Activity Cost of Waste Management Service

\begin{tabular}{|c|l|c|c|r|c|}
\hline \multirow{2}{*}{ No } & \multirow{2}{*}{$\begin{array}{c}\text { Service } \\
\text { Activities }\end{array}$} & \multicolumn{1}{|c|}{ BTKL } & \multicolumn{1}{|c|}{ O\& P } & Administration & Total (Rp) \\
\cline { 3 - 6 } 1 & $\begin{array}{l}\text { Street } \\
\text { sweeping }\end{array}$ & 13.328 .682 .000 & 363.286 .606 & 158.274 .400 & 13.850 .243 .006 \\
\hline 2 & $\begin{array}{l}\text { transporting } \\
\text { waste }\end{array}$ & $\mathbf{7 4 0 . 5 8 0 . 0 0 0}$ & 3.564 .470 .999 & 1.552 .147 .350 & 5.857 .198 .349 \\
\hline 3 & $\begin{array}{l}\text { Management } \\
\text { at the landfill }\end{array}$ & 630.006 .000 & 1.355 .320 .895 & 590.078 .250 & 2.575 .405 .145 \\
\hline \multicolumn{7}{|c|}{ Total } & $\mathbf{1 4 . 6 9 9 . 2 6 8 . 0 0 0}$ & $\mathbf{5 . 2 8 3 . 0 7 8 . 5 0 0}$ & $\mathbf{2 . 3 0 0 . 5 0 0 . 0 0 0}$ & $\mathbf{2 2 . 2 8 2 . 8 4 6 . 5 0 0}$ \\
\hline
\end{tabular}

\section{Rate Per Cost of Pool}

Calculation of the cost of services by using the ABC method imposes system overhead to services based on the activities undertaken to generate such services. The amount of service fee per unit is calculated by dividing the total cost of the cost pool each activity with the amount of output at the event. To more clearly shown in Table 13.

Table 13 Rates Cleanness Services Per Cost of Pool 


\begin{tabular}{|c|l|r|r|r|r|}
\hline $\mathrm{N}_{0}$ & \multicolumn{1}{|c|}{ Service Activities } & \multicolumn{1}{|c|}{ Total $(\mathrm{Rp})$} & \multicolumn{2}{|c|}{ Cost Driver } & Rate (Rp) \\
\hline 1 & Strect sweeping & 13.850 .243 .006 & 144.0000 & $\mathrm{Km}$ & $6.275,35$ \\
\hline 2 & transporting waste & 5.857 .198 .349 & 60.488 & Trip & $96.832,40$ \\
\hline 3 & Managementat the landfill & 2.575 .405 .145 & 410.400 & $\mathrm{~m}^{3}$ & $6.275,35$ \\
\hline
\end{tabular}

From Table 13 above can be seen that sweeping rate (cost pool A) is Rp. $96182 / \mathrm{km}$; the transport rate (cost pool B) is Rp. 96832.40/trip and the landfill management rate (cost pool C) is Rp. $6275.35 / \mathrm{m}^{3}$.

\section{Rate per Volume Solid Waste}

Street sweeping activities based guidelines for the management of urban solid waste management (Directorate General of urban planning and rural planning, 2003) street sweeping protocol manually with a ratio of 1 officer: $1 \mathrm{~km}$ long strokes with a maximum of $1.5 \mathrm{~m}^{3}$ of waste collected, so for street sweeping per $\mathrm{m}^{3}$ is $\mathrm{Rp}$ 6275.35: $1.5 \mathrm{~m}^{3}=\operatorname{Rp} 4,184 / \mathrm{m}^{3}$.

Based on data from the Cleaning dan Landscaping Agency, the volume of container used to transport garbage average of $7 \mathrm{~m}^{3}$ per unit, so the per ritasi will be transported garbage as much as $7 \mathrm{~m}^{3}$. The cost of transporting waste services per ritasi known Rp.96.832.40/trip so the cost per $\mathrm{m}^{3}$ of waste is Rp.96.832,40: $7 \mathrm{~m}^{3}=$ Rp. $13.833 / \mathrm{m}^{3}$. While the cost per $\mathrm{m}^{3}$ of solid waste that must be managed in the landfill is Rp. $6.275 .35 / \mathrm{m}^{3}$. So from these calculations, the amount of solid waste and sanitation services tariff per $\mathrm{m}^{3}$ of waste is the sum of the cost of services that can be seen in Table 14.

Table 14 Cost Per $\mathrm{m}^{3}$ Waste Services

\begin{tabular}{|c|c|c|c|}
\hline No & Activities & $\begin{array}{c}\text { Rate } \\
(\text { Rp./m²) }\end{array}$ & Description \\
\hline 1 & $\begin{array}{l}\text { Street } \\
\text { sweeping }\end{array}$ & 4.184 & $\begin{array}{c}1 \mathrm{~km} \text { equal } 1,5 \mathrm{~m}^{3} \\
\text { solid waste }\end{array}$ \\
\hline 2 & $\begin{array}{l}\text { transporting } \\
\text { waste }\end{array}$ & 13,833 & $\begin{array}{c}1 \text { trip equal } 7 \mathrm{~m}^{3} \text { solid } \\
\text { waste }\end{array}$ \\
\hline 3 & $\begin{array}{l}\text { Landfill } \\
\text { management }\end{array}$ & $6.275,35$ & \\
\hline \multicolumn{2}{|r|}{ Total } & 25.0000 & (Roung Off) \\
\hline
\end{tabular}

Based on the research results of waste, published by the Research and development for Settlement Division, Ministry of Public Works in Table 15.

Table 15 Level of Urban Waste

\begin{tabular}{|c|c|c|c|c|c|}
\hline No & $\begin{array}{c}\text { Source } \\
\text { Genel'ition } \\
\end{array}$ & Unit & Generate & $\begin{array}{l}\text { Justifikasi } \\
\left(\mathrm{m}^{3} / \mathrm{hari}\right)\end{array}$ & $\begin{array}{c}\text { Rate } \\
\text { (Dikali Rp. 25.0000) }\end{array}$ \\
\hline 1 & Household & Liter/org/day & $1,75-2,50$ & 0,0025 & Rp.63 \\
\hline 2 & Commercial & Liter/peg/day & $2,50-3,00$ & 0,0022 & Rp. 55 \\
\hline 3 & Public & Literi/peg/day & $0,10-0,15$ & 0,0007 & Rp. 18 \\
\hline & facilities & & & & \\
\hline 4 & RoadProtocol & Liter/ $/ \mathrm{m}^{2} / \mathrm{day}$ & $0,10-0,20$ & 0,0002 & Rp. 5 \\
\hline 5 & Market & Liter/ $/ \mathrm{m}^{2} / \mathrm{day}$ & . & 0,0055 & Rp. 138 \\
\hline 6 & Industry & Liter/unit/day & - & 0,4832 & Rp 12.080 \\
\hline \multicolumn{2}{|c|}{ Total } & & & 0,4943 & Rp. 12.359 \\
\hline
\end{tabular}

V. CONCLUSIONS

Construction Project Management
Based on the results of this study the following conclusions are drawn :

1. Solid waste management expense consist of TPS (temporary collection location/Tempat penampungan sementara) investment, operational/maintenance of TPS, wipe of general facility, transport from TPS to landfill and landfill treatment.

2. The result from this study show that cost of street sweeping is Rp. 6.275,35/km; cost of transporting solid waste is Rp. 96.832,40/trip and cost of landfill treatment is Rp. $6.275,35 / \mathrm{m}^{3}$

3. Modelling tariff retribution calculate based on solid waste generated each type building.

\section{REFERENCES}

[1] Carter, Usry, (2006). Cost Accounting, Salemba Empat, Jakarta.

[2] Directorat of Sanitation, (2011), Guideliness for Solid Waste Management, Ministry of Public Work, Jakarta

[3] Horngren (2008), Cost Accounting, Erlangga, Jakarta

[4] Irawan, Guntur, (2013), Analyze Determination of the Basic Rate Retribution Cleanliness at Palu City Based on Activity Based Costing System, Thesis, Environment Technology FTSP-ITS, Surabaya

[5] Mulyadi, (2010), Cost Accounting, STIE YKPN, Yogyakarta. 